\title{
Ludorugbya springbokorum (Pottiaceae) a new moss genus and species from the Western Cape Province of South Africa
}

\author{
TERRY A. HEDDERSON ${ }^{1}$ and RICHARD H. ZANDER ${ }^{2}$ \\ ${ }^{1}$ University of Cape Town, South Africa and ${ }^{2}$ Missouri Botanical Garden, U.S.A.
}

\begin{abstract}
SUMMARY
We describe Ludorugbya springbokorum, a new genus and species of Pottiaceae from the Cape Floristic Region of South Africa. It is gametophytically distinct in the small plants with ovate-lanceolate to spathulate, redawned, plane-margined leaves that are red in $\mathrm{KOH}$, usually bistratose in $1-2(-4)$ transverse rows at the insertion, with a differentiated border, and a costa section with a semicircular dorsal stereid band, a dorsal epidermis and a differentiated pad of cells on the ventral surface. The immersed, cupulate to short-cylindric capsules with a very long-conic operculum, very poorly developed peristome, and an evertable annulus are also highly distinctive. Spore dispersal is controlled by the annulus, which when dried is rolled inwards, almost closing the capsule mouth, but everts rapidly on wetting, expanding the rim of the capsule mouth. Spore size is distinctly bimodal within individual capsules and highly variable between capsules. At present L. springbokorum is known only from remnant renosterveld patches in the Swartland region of South Africa, and within this highly transformed landscape the species appears to be rare and under considerable threat.
\end{abstract}

KEYWORDS: Pottiaceae, Ludorugbya, anisospory, evertable annulus, renosterveld, habitat fragmentation, Cape flora.

INTRODUCTION

The Pottiaceae (Bryophyta; Dicranidae), a family particularly characteristic of harsh environments, are an important constituent of many arid zone floras (Zander 1993). This may be especially true of areas of Mediterranean (winter wet) climate, which often show both high diversity and considerable levels of endemism for the family (e.g. Scott, 1982; Zander, 1993; Guerra, Cano \& Ros, 2006).

The winter rainfall area of South Africa is no exception. Although still poorly known in comparison with some other areas of Mediterranean climate, the region includes many Pottiaceae, including a relatively large proportion of endemics (Magill, 1981; Van Rooy, 2003; O'Shea, 2006; Hedderson \& Zander, 2007). Collections made by the first author over the past few years include a large number of novel species, and are further evidence of the presence of a highly diverse and apparently unique Pottiaceous flora in the Cape Floristic Region. In the present paper, we describe one of these distinctive entities, apparently restricted to remnant renosterveld shrublands, as a new genus and species.

(c) British Bryological Society 2007

DOI: $10.1179 / 174328207 X 229742$

\section{DESCRIPTION}

Ludorugbya springbokorum Hedd. \& R.H. Zander gen. et sp. nov. (Fig. 1)

Plantae sparsae vel gregariae vel laxe caespitosae. Folia late ovato-lanceolata vel spathulata, in lamina superna concava, marginibus planis integris vel interdum in parte apicali denticulatis, leniter per cellulas 1-3 angustiores minus papillosas marginata; costa robusta, in aristam rubram (raro hyalinam) excurrens, strato stereidarum dorsali distincto semicirculari, epidermide dorsali atque ventrali praesenti, cellulis ventralibus recte elongatis pulvillum distinctum tumescens formantibus, funiculo hydroide praesenti; cellulae basales abrupte valdeque in parte folii basali distinctae, vulgo bistratosae ad insertionem vel raro in areis parvis marginalibus proxime super insertionem in seriebus transversis 1-2(-4). Dioica. Folia perichaetialia interiora valde distincta. Seta brevis, 0.18 $0.25 \mathrm{~mm}$. Capsula brevis, in foliis perichaetialibus immersa, in statu sicco late ellipsoidalis (doliiformis), madido cupulata et sub ore constricta, subsulcata, ad basem truncata, abrupte ad setam angustata; annulus persistens

Received 30 May 2007. Revision accepted 28 August 2007 


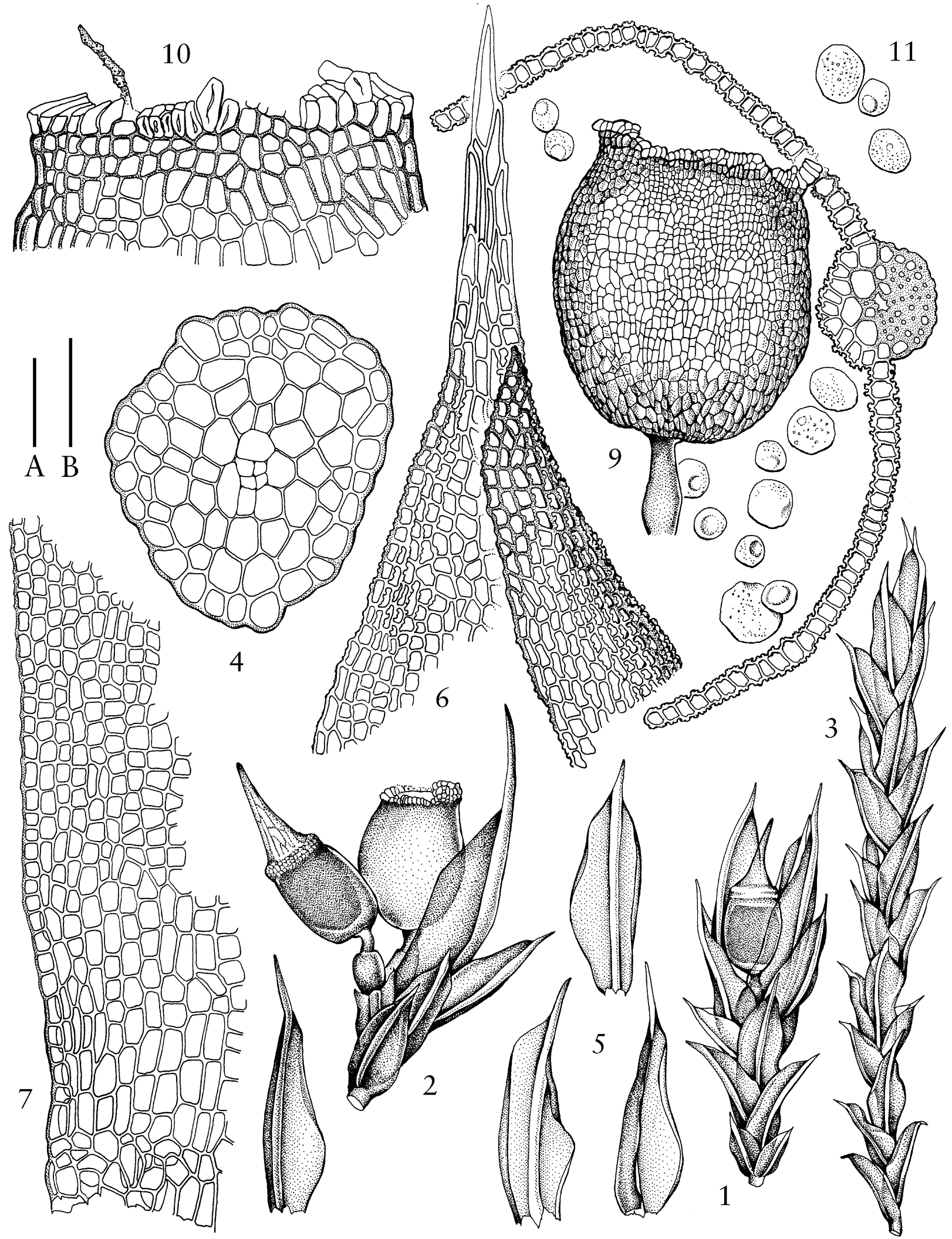

Figure 1. Ludorugbya springbokorum (all from the type): 1, habit of sporulating plant; 2, perichaetium with two sporophytes; 3 , sterile shoot 4, transverse section of stem; 5 , leaves; 6 , leaf apex; 7, cells at leaf base; 8 , transverse section of leaf just above middle; 9 , sporangium; 10 , cells at rim of capsule with portions of the evertable annulus and a peristome tooth; 11 , spores. Scale bars: A, 1 and $3=0.5 \mathrm{~mm} ; 2$ and $5=$ $0.4 \mathrm{~mm}$; B, $6-8$ and $10=50 \mu \mathrm{m} ; 9=75 \mu \mathrm{m} ; 11=40 \mu \mathrm{m}$. 
e cellulis in seriebus 3-4 valdissime incrassatis, inflexus, in sicco os capsulae fere tegens, in madido evolutus (eversus); peristomium deminutissimum, in capsulis paucis nullum sed quum praesens e dentibus 16 brevibus, articulis $4-5$ cinerascentibus vel flavo-brunneis vel hyalinis papillosis compositum. Operculum longi-conicum, atque longum ac thecam vel fere longius. Calyptra conica vel longi-mitrata, cellulis paucis proratis papillas sparsas formantibus. Sporae in distributione amplitudinis distincte bimodali.

Type: South AfricA: Western Cape Province. Malmesbury Area, Rustenberg Farm, 33 $30^{\prime} 01^{\prime \prime} \mathrm{S}$, $18^{\circ} 41^{\prime} 58^{\prime \prime} \mathrm{E}, 3318 \mathrm{DA}$. Forming turves on clay in remnant renosterveld patch on steep S-facing clay-shale slope, $170 \mathrm{~m}$. Hedderson 15900, 25 January 2005. HоLOTYPE BOL; ISOTYPE MO.

Paratypes: South Africa: Western Cape Province, Malmesbury Area, Rustenberg Farm, remnant renosterveld patch on steep south-facing clay-shale slope, on dry clay bank, 3318DA, Hedderson 15897, 15991 BOL. Riebeek Kasteel area, Wynkeldershoek, remnant renosterveld patch on east- and north-facing slopes, 3318BD, Hedderson 15986, 15988 BOL. Moorreesberg area, Kammelvlei, remnant renosterveld patch, 3318BB, Rugengamanzi s.n. BOL.

Plants terricolous, scattered to gregarious or forming loose turf, or sterile plants somewhat elongate and \pm intertwining, pale yellow-green to dark green. Stems simple, or fertile plants sometimes with $2-4$ slender innovations from near base, $2.5-6.0 \mathrm{~mm}$, transverse section round, central strand present but weak and only comprising 2-3 cells, sclerodermis absent, hyalodermis absent, cortex of thin-walled cells with epidermal layer slightly thickened on external surface; axillary hairs of 4-6 rectangular to longelliptic, thin-walled cells, all hyaline or basal 1-2 cells slightly thicker-walled. Leaves erect, slightly contorted and loosely folded along midline when dry, erect to erectspreading when wet, broadly ovate-lanceolate to spathulate, $0.8-1.4 \mathrm{~mm}$ long, upper lamina concave, margin plane, entire or sometimes denticulate in uppermost part, with a weakly differentiated border of 1-3 narrower, thickerwalled and less papillose cells; costa strong and excurrent in a red (rarely hyaline) awn, superficial cells elongate and smooth dorsally, quadrate to short-rectangular and papillose ventrally, transverse section round, dorsal stereid band strong, semicircular, ventral stereid band absent, dorsal and ventral epidermis present, ventral cells vertically elongated and forming a distinct, bulging pad, guide cells 4-5 in a single layer, hydroid strand present; upper and mid laminal cells subquadrate (rarely oblate) to short rectangular (10-) 13-18(-24) $\mu \mathrm{m}$ long $\times 8-12 \mu \mathrm{m}$ wide, rather strongly and unevenly thickened to \pm collenchymatous, papillae hollow, simple, 3-6 per cell; basal cells abruptly and strongly differentiated in $c a$ lower $1 / 3$ of leaf, long rectangular, 12$18 \mu \mathrm{m}$ wide, $3-5: 1$, walls firm, bordered by $1-3$ rows of narrower and somewhat thicker-walled cells, commonly bistratose in $1-2(\times 4)$ transverse rows at insertion or rarely in marginal patches just above insertion.
Dioicous. Perichaetia terminal, inner leaves strongly differentiated, larger (1.2-1.9 mm long), broadly ovatelanceolate with a sheathing base, differentiated thin-walled basal cells extending 1/2 way or more up leaf. Perigonia terminal, upper leaves of perigoniate plants with hyaline awn and lacking a border, vegetative leaves as described above, antheridia immature. Seta short, $0.18-0.25 \mathrm{~mm}, 1-2$ per perichaetium, hyaline to clear brown, straight. Capsule short, immersed in perichaetial leaves, $0.44-0.75 \mathrm{~mm}$ long, pale to yellow-brown, broadly ellipsoidal (barrel-shaped) when dry, cupulate to short-cylindrical and constricted below mouth when wet, weakly sulcate wet or dry, base truncate and narrowed abruptly to seta; exothecial cells quadrate to short rectangular, $18-30 \mu \mathrm{m}$ wide, 1-2.5:1, thin-walled; stomata phanerophore, restricted to very base of capsule; annulus persistent, of 3-4 rows of very strongly thickened cells, inflexed and almost covering mouth when dry, evolute (everted) when moist; peristome very reduced, absent in some capsules but when present of 16 short teeth with 4-5 articulations, greyish to yellow brown or hyaline, papillose. Operculum long-conic, as long as or somewhat exceeding the theca. Calyptra conic to long-mitrate, base sometimes split to form uneven lobes, $c a 0.5 \mathrm{~mm}$ long, covering operculum, reddish yellow, cells rectangular, rather thick walled, some prorate, forming scattered papillae. Spores spherical to slightly ellipsoidal, brownish, with a distinctly bimodal size distribution, usually with the smaller $11.5-16.0 \mu \mathrm{m}$ and the larger $17.0-24.5 \mu \mathrm{m}$ but some capsules with the smaller 13.5-21.0 $\mu \mathrm{m}$ and the larger 26.0-34.5 $\mu \mathrm{m}$.

\section{Laminal $\mathrm{KOH}$ colour reaction red.}

The genus name pays homage to the game of rugby, whilst the species name honours particularly the superlative style of the sport as played by the South African national side. The epithet is appropriate on several counts. A passion for the game led directly to the discovery of the species as the first collections were made during a diversion from field studies to a nearby town to watch a televised Springbok match. In addition the capsule in the dry state has much the shape of a rugby ball. Finally both the moss and the Springbok side epitomize toughness and perseverance in the face of adversity; may both continue to flourish.

\section{DiscUSSION}

When fertile, Ludorugbya can scarcely be mistaken for any other moss. The small plants, with ovate-lanceolate to spathulate, red-awned leaves, bearing immersed cupulate to short-cylindric capsules (in the wet state) with a very longconic operculum and an evertable annulus are diagnostic. Sterile material is also distinct, at least microscopically, in the plane leaves that are red in $\mathrm{KOH}$, having a differentiated border and a costa section with a semicircular dorsal stereid band, a dorsal epidermis, and a differentiated pad of cells on the ventral surface. Another distinctive feature that may help identification of sterile plants is the base of cauline leaves bistratose in 1-2(-4) transverse rows 
at the insertion, or occasionally these cells unistratose but somewhat thicker walled. The anisosporous condition is also uncommon in the Pottiaceae having previously been reported only for two species of Leptodontium, $L$. viticulosoides (P. Beauv.) Wijk \& Margad. and L. wallisii (Mull.Hal.) Kindb. (Anderson \& Zander, 1986; Zander, 1993), and in Tortula laevipila Brid. (Gallego, Cano \& Guerra, 2004).

The new genus is distinguished from Tortula Hedw. and its relatives by the brick-red colour in $2 \% \mathrm{KOH}$ solution. Among similar genera that respond brick red in $\mathrm{KOH}$, the relatively small leaf cells and plane leaf margins distinguish Ludorugbya from Microbryum Schimp. and the presence of a dorsal epidermis in the costa from Syntrichia Brid. and Willia Müll.Hal. The basal cells are also rather firm-walled compared with Willia and Syntrichia, and the plants are smaller than normal for both these genera. It differs further from Syntrichia in the reduced sporophyte, a feature never evinced in that genus. In addition, the dorsal stereid band is usually crescentic rather than semicircular in that genus. It is perhaps morphologically most akin to Hennediella Paris, which has similar bordered, plane-margined leaves, but differs in the smaller leaf cells, the strongly differentiated, sheathing perichaetial leaves, the distinctive sporophyte with very short seta, urceolate capsule with a persistent, vesiculose annulus strongly everted when moist, and the conic-mitrate, prorulose-papillose calyptra.

Control of spore dispersal in the new species is unusual. The highly reduced (frequently absent) peristome appears to play little or no role. Rather the capsule mouth is opened or closed by the highly developed annulus. When dry, the annulus rolls into the capsule mouth, drawing with it the rim of the capsule and greatly narrowing or effectively closing it. When wet, the annulus everts rapidly, pulling the capsule mouth outward into a flared rim and leaving the mouth widely open. Spore release would therefore seem to be possible only under wet conditions.

To our knowledge, this annular control mechanism is otherwise known only in Leucoperichaetium eremophilum Magill, known from southernmost Namibia (Magill, 1981). That species also has a similar urceolate to short-cylindric urn, but the operculum is low, and the gametophyte is consistent with its current placement in Grimmiaceae. This apparent convergence on an unusual dispersal solution in two distantly related lineages is remarkable, and suggests that the local environments might provide strong selection favouring this mode of dispersal. The selective advantage of this dispersal mechanism remains obscure. Dispersal distances are likely to be reduced when spores are shed under wet conditions, but possibly establishment is enhanced. Critical in interpreting this feature would be information on spore longevity and dormancy.

Pottia namaquensis Magill also has a sporophyte similar to Ludorugbya, sharing the urceolate shape (rare in Pottiaceae), a conic operculum, and a mitrate, papillose to spiny calyptra (Magill, 1981; pers. obs.). It, too, has a persistent annulus of 3-4 rows of vesiculose cells. The peristome is, however, more or less well developed, and the annulus is not at all hygroscopic and plays no obvious role in closing the capsule or controlling spore dispersal in any other way. The gametophyte is very unlike that of Ludorugbya, and is much more like that of Syntrichia, where that distinctive species may belong.

Spore size distributions in Ludorugbya springbokorum are also unusual. In individual capsules spore sizes are always bimodal (Fig. 2), but the relative proportions of the two size classes are highly variable. In addition the actual sizes of the two fractions vary greatly among capsules. In a number of taxa exhibiting anisospory, the smaller fraction is often deformed and apparently inviable, prompting Mogensen $(1978,1981)$ to suggest the existence of lethal genetic factors. In the present case, however, there are no observable differences among the two fractions apart from size, and there is no reason to think that the smaller fraction is inviable. If sexuality is chromosomally determined, it is also unlikely that the differences correspond to different sexes since these would be expected then to occur in a 50 : 50 ratio. Clearly more populations need to be studied,

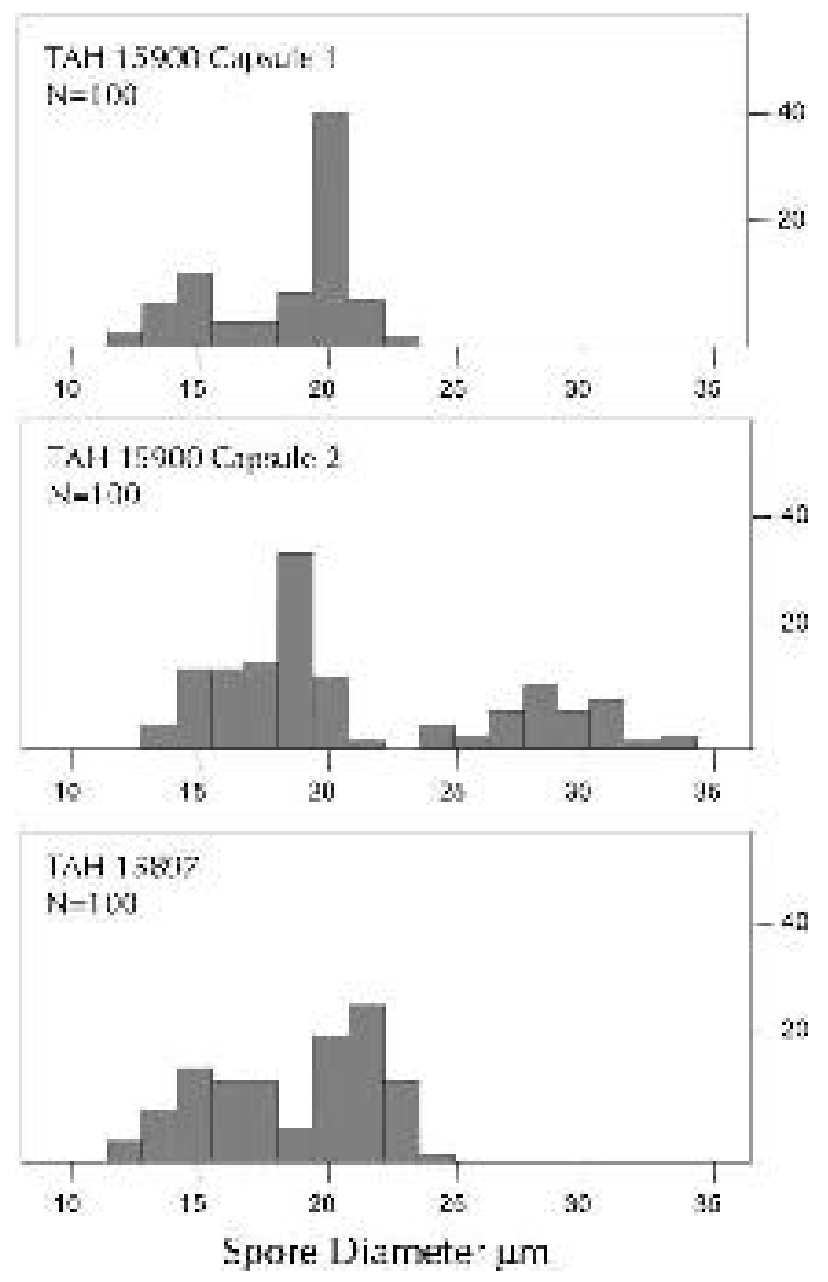

Figure 2. Variation in spore size in three capsules of Ludorugbya springbokorum. Numbers on vertical axes are frequencies. (From Hedderson 15900, 15897) 


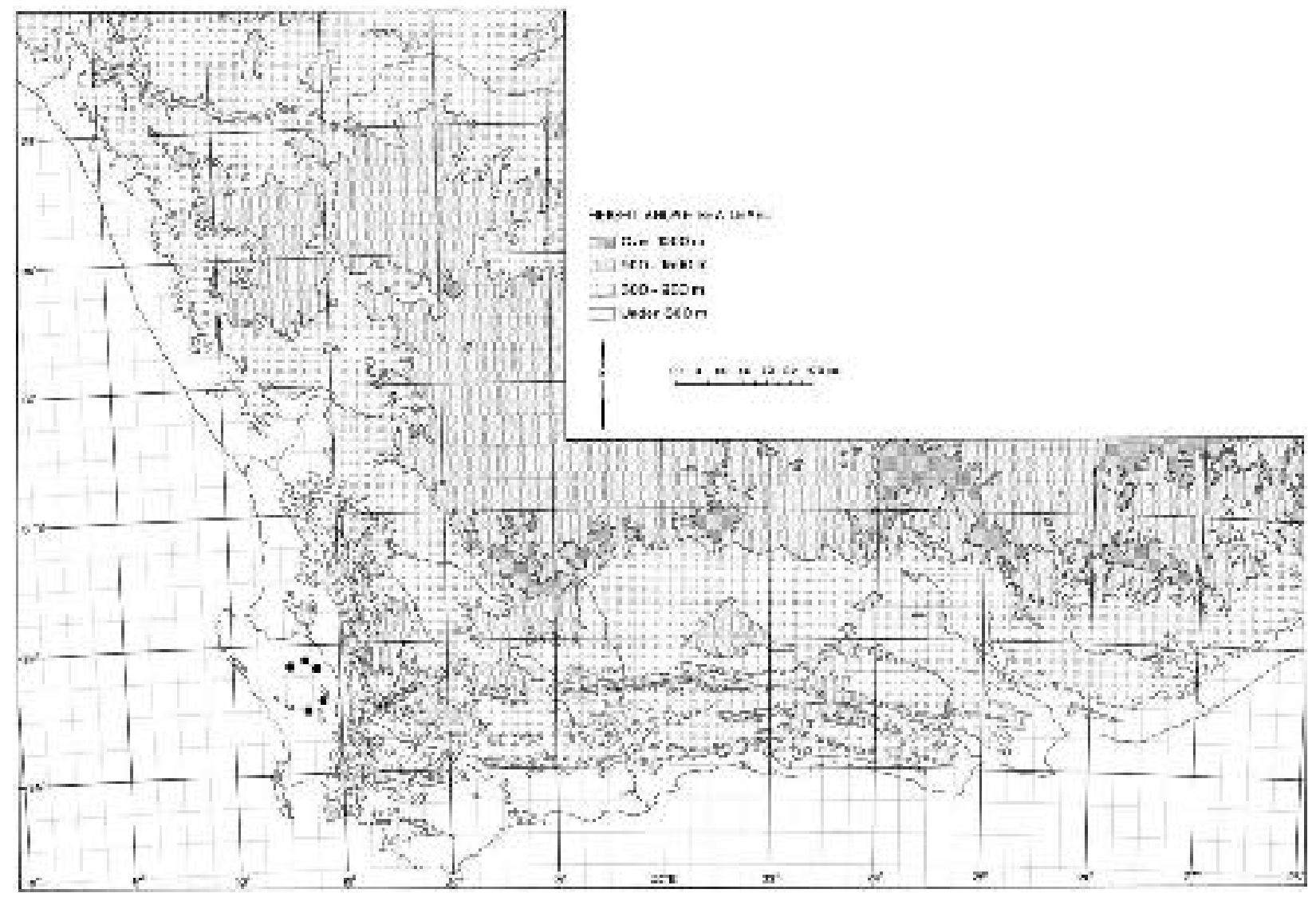

Figure 3. Map of southern and western South Africa showing the known distribution of Ludorugbya springbokorum.

in conjunction with cultivation experiments, to understand the genetic basis of spore size variation in this taxon.

Ludorugbya springbokorum is currently known only from renosterveld fragments in the Swartland region of the Western Cape (Fig. 3). This vegetation type is one of the most threatened in South Africa, and by recent estimates $<5 \%$ of the original extent of west coast renosterveld remains, much of it as tiny fragments in an agricultural or otherwise transformed landscape (Low \& Rebelo, 1996; Donaldson et al., 2002). In a recent survey of remnant west coast renosterveld patches (T. A. Hedderson, J. Watson \& F. N. Rugengamanzi, unpublished data) this species was found in only five of $47(11 \%)$ sample localities, and the only known fruiting specimens both come from a single, particularly well-preserved, site. That study also showed that $L$. springbokorum is present only in the largest and least isolated patches, indicating that it may be vulnerable to extinction as a result of 'relaxation' phenomena during fragmentation. The existing data therefore suggest that this unique taxon may be among the world's most threatened moss species.

\section{ACKNOWLEDGEMENTS}

We would like to thank the Boere of the Swartland for permission to access field sites and for their ever-generous hospitality. We are also grateful to Patricia Eckel for the illustrations and the Latin diagnosis, and to the Missouri
Botanical Garden for access to their extensive facilities. The University of Cape Town and The National Research Foundation of South Africa provided funding.

TAXONOMIC ADDITIONS AND CHANGES: Ludorugbya springbokorum Hedd. \& R. H. Zander, gen. et sp. nov.

\section{REFERENCES}

Anderson LE, Zander RH. 1986. False anisospory in the moss Leptodontium viticulosoides (P.-Beauv.) Wijk. \& Marg. American Journal of Botany 73: 603.

Donaldson JD, Nanni I, Zacharides C, Kemper J. 2002. Effects of habitat fragmentation on pollinator diversity and plant reproductive success in renosterveld shrublands of South Africa. Conservation Biology 16: 1267-1276.

Gallego MT, Cano MJ, Guerra J. 2004. A taxonomic study of Syntrichia laevipila (Pottiaceae, Musci) complex. Botanical Journal of the Linnean Society 145: 219-230.

Guerra J, Cano MJ, Ros RM. 2006. Flora Briofitica Ibérica Pottiales: Pottiaceae, Encalyptales: Encalyptaceae, Vol. 3. Murcia: Universidad de Murcia \& Sociedad Española de Briología.

Hedderson TAJ, Zander RH. 2007. Triquetrella mxinwana, a new moss species from South Africa, with a phylogenetic and biogeographic hypothesis for the genus. Journal of Bryology 29: 151-160.

Low AB, Rebelo AG. 1996. Vegetation of South Africa, Lesotho and Swaziland. A companion to the vegetation map of South Africa, Lesotho and Swaziland. Pretoria: Department of Environmental Affairs and Tourism.

Magill R. 1981. Flora of Southern Africa. Bryophyta. Part 1. Mosses. Fascicle 1. Sphagnaceae-Grimmiaceae. Pretoria: Botanical Research Institute. 
Mogensen G. 1978. Spore development and germination in Cinclidium (Mniaceae, Bryophyta), with special reference to spore mortality and false anisospory. Canadian Journal of Botany 56: 1032-1060.

Mogenesen G. 1981. The biological significance of morphological characters in bryophytes: the spore. Bryologist 84: 187-207.

O'Shea B. J. 2006. Checklist of the mosses of sub-Saharan Africa (version 5). Tropical Bryology Research Reports 6: 1-255.
Scott GAM. 1982. Desert bryophytes. In: Smith AJE, ed. Bryophyte ecology. London: Chapman \& Hall, pp. 105-122.

Van Rooy J. 2003. Pottiaceae. In: Germishuizen G, Meyer NL, eds. Plants of Southern Africa: an annotated checklist. Strelitzia 14: Pretoria: National Botanical Institute, 27-32.

Zander RH. 1993. Genera of the Pottiaceae: mosses of harsh environments. Bulletin of the Buffalo Society for Natural Sciences 32: $1-378$.

Terry A. J. Hedderson, Bolus Herbarium, Department of Botany, University of Cape Town, Private Bag, 7701 Rondebosch, South Africa. E-mail: thedders@egs.uct.ac.za

Richard H. Zander. Bryology Group, Missouri Botanical Garden, PO Box 299, St Louis, MO 63166, U.S.A. 